\title{
The Effect of Parenting Patterns and Birth Order towards the Independent Social Behavior of Kindergarten Children in Gugus Anggrek, East Banjarmasin District
}

Rakhmawati *, Rustam Effendi, Darmiyati

Master Program of Early Childhood Teacher Education, Universitas Lambung Mangkurat, Banjarmasin 70123, Indonesia

\begin{tabular}{|c|c|}
\hline ARTICLE INFO & ASTRACT \\
\hline $\begin{array}{l}\text { Article history } \\
\text { Submission: November } \\
\text { 20I9 } \\
\text { Revised: February } 2020 \\
\text { Accepted: March } 2020 \\
\text { Keywords: Influence, } \\
\text { Parenting pattern, Birth } \\
\text { order of the child, Social } \\
\text { behavior, Childs' }\end{array}$ & $\begin{array}{l}\text { The problems that occur at this time are many children who are still dependent on } \\
\text { their parents to do every activity. Independent attitude is very dependent on } \\
\text { parents, often children cry when they stay for a while by their mother or caregiver. } \\
\text { This study describes the influence of parenting on the birth order of children } \\
\text { towards independent social behavior using a quantitative and path analysis. The } \\
\text { research sample was obtained from } 2 \text { I } 4 \text { children aged } 5-6 \text { years using the simple } \\
\text { random sampling technique and the Slovin formula from a population of } 445 \\
\text { Kindergarten children in Gugus Anggrek, East Banjarmasin District. Also, data were } \\
\text { collected through questionnaires, documentation, and observation. The results } \\
\text { showed that parenting patterns affect the birth order of children towards their } \\
\text { independent social behavior. }\end{array}$ \\
\hline & $\begin{array}{l}\text { (C) (1) (2) } 2019 \text { The Authors. Journal of K6, Education, and Management } \\
\text { (j-K6EM). ISSN: 2580-2135. Published by Graduate Program of } \\
\text { Educational Management, Universitas Lambung Mangkurat, } \\
\text { Banjarmasin 70123, Indonesia. This is an open-access article under the CC-BY-SA license. }\end{array}$ \\
\hline
\end{tabular}

*Correspondence: Rakhmawati; E-mail: farahadityaI@gmail.com 


\section{Introduction}

Every human being acquires knowledge from childhood to adulthood through education. Teachers and students, make up the educational system and both are important to ensure the learning process is properly conducted. It is also a medium for everyone to obtain learning at each point in life, therefore, it can produce emotional, intellectual, and spiritual intelligence of those engaged in the process.

Furthermore, its associated relationship with human resources is an important aspect of every organization or institution. It consists of teachers who are essential commodities to the proper running of an institution. A teacher is required to be creative and initiative with adequate knowledge of the rapidly developing scientific and technological advances, as well as high professional experience in transferring knowledge to students (Hamdanah, 2017).

According to Law Number I4 of 2005 concerning Teachers and Lecturers, "teachers are professional educators with the main task of educating, teaching, guiding, directing, training, and evaluating students through formal, basic education, and advanced education from early childhood to adulthood. They play important roles in $\mathrm{s}$ the formation of children's character at an early stage. Similarly, parents also play the same role as the first people to educate children. Educational institutions also consist of people with PAUD also known as the highest qualification. The strategies undertaken by parents and the community in creating student character are effective reciprocal communication with the school and effective and mutually beneficial partnerships (Suriansyah and Aslamiah, 2015).

The education obtained by children from parents is commonly referred to as informal which proceeds to in schools, where they are taught to form a better personality. This early childhood education institution is contained in Law no. 20 article 28 paragraph 3 , which states that "Early childhood education consists of formal channels in the form of kindergarten (TK), Raudatul Athfal (RA), or another equivalent which helps to form their character. With the presence of educational institutions such as PAUD, independent child character and personality of students are formed as they age.
The purpose of early education aims to embed the social aspects of children's behavior which reflects their independence at an early age through primary school education (Safitri et al., 2018).

Early childhood is a golden age, where development greatly determines a Childs future personal character. It is presently a process of growth in various aspects of human life in the age range of one to five years (Susanto, 2017). At the level of children's education found in Indonesia, ideally formal is that students enter the PAUD education phase, this phase of the child is proceeding to his development and potential.

It aims to develop potential aspects in children (Zain et al., 2018). Furthermore, growth and development need to be directed to lay proper foundations for physical, creative, emotional, social, language, and balanced growth, thereby, realizing quality in children at an early age.

Early childhood education is the provision of efforts to stimulate, guide, nurture, and provide learning activities that produce children's abilities and skills. It covers all the efforts and actions taken by educators and parents in the process of care and providing education to children by creating an environment, where they explore experiences that provide an opportunity for them to understand experiences acquired in the environment, through observation, imitation, and experimenting.

Children are also taught to learn independently, to assists them conduct activities independently when they become adults without having to depend on others. The role of the family is very necessary to establish early independence. Parenting conducted at home tends to determine a child's social behavior and independence.

In kindergarten children between the ages of 4-5 years, the development of independence is marked by being happy and assisting their mothers with home chores such as sweeping, cooking, watering plants, etc. Similarly, they tend to show signs of being able to bath, brush their teeth, wear dress up (Susanto, 2017).

According to Erikson, the critical period for the development of independence takes place at the ages of 2-3 years. At that age, assuming independence is not developed, delays occur. Therefore, your child tends to keep depending on 
others as a teenager, and an adult later in life (Rakhma, 2017). Daily activities such as eating, bathing, clothing, etc, help to make a child independent.

Nowadays, parents easily surrender to children's education at school. Furthermore, a western culture that is very close to children also affects their lives from various aspects such as how to dress, get along with others, behavior, and mindset. A good education is realized when it is based on a strong religious foundation and supported by the existence of a balance of education in school and at home (cooperation) (Afifah et al., 2019).

Independence is conducting an activity based on one's motivation. Therefore, when children insist on brushing their teeth, combing their hair, pouring water into a glass, or even feeding themself, give them a chance. At the age of 3-4 years, they want to conduct everything on their own accord. This behavior which occurs due to their motor skills ad curiosity makes them stand out.

Many studies show that children, especially in Indonesia, often experience delays in independence because their parents assist them in conducting all activities (Fadillah and Khorida, 2016). Various observations found that Indonesia children are in the category of slow in terms of independence due to parents' selfless awareness in practicing independence (Latifah and Metroyadi, 2019).

Independence makes children capable of being responsible for themselves. Criteria used to identify them as independent, including the ability to be left alone for 2-3 hours, use the toilet by themselves, excited to go to school, have an adequate idea of the items they carry, able to wear their clothes, know their gender, brush their teeth, know their parent's names, phone numbers, understand traffic signs, able to carry plates, control themselves, play with their friends, talk easily and, carry out simple tasks, carry out activities on their own, etc (Wiyani, 2015). An Independent attitude depends on parents. Children tend to cry having stayed for a while with their mother or caregiver, to obtain attention and help of those around them. In general, this attitude is formed due to excessive spending on adults by serving them past the age limit required for them to start conducting their activities. Children allowed to develop independently tend to become more confident in carrying out activities at later stages in life (Wahdini, 2019).

Independence in children becomes the target of parents, therefore, each learning phase familiarizes them with their environment. Thit is also achieved through parental guidance and examples. When an adult or family member provides opportunities for children to conduct their activities, they grow to possess high selfconfidence which makes them dare to make correct decisions, get acquainted with their abilities, and accept their uniqueness. Independent children work hard in achieving academic success, and conduct tasks independently.

In families, parents are required to possess managerial and technical skills. They are also required to possess several good leadership skills with the ability to win the hearts of children, foster harmonious relationships, master their technical skills, provide good examples, and training (Nur and Karismatika, 2019).

Parenting patterns in the family appear in various styles as follows authoritarian, democratic, laicizes-faire, paternalistic, charismatic, self-fusion, pioneer, manipulation, transaction, origin, survival, role transfer, selflessness, consultant and militaristic (Djamarah, 20I4). Types of parenting affect the social behavior of children because parents or family is the first environment that gives influence to various aspects of child development, including social. Parenting patterns applied by parents at home will influence how the child's social behavior and children's independence at school. According to Pintrich, independent children are children who can combine motivation and cognitive as well (Susanto, 2017). That is, it can be said that being an independent child depends on self-confidence and motivation. Each child tends to be independent or have independent potential.

Closely monitored children find it difficult to obtain independence. However, a wise attitude and proper treatment tend to trigger their independence. Overprotective parents are too watch over their children, owing to fear of being dirty, damage, and an accident, which tends to be fatal. Sylvia Rim stated that to foster a child's confident attitude means being happy to see them succeed and disappointed at their bad attitude (Susanto, 2017).

Similarly, the birth order of children in the family, such as first, middle, or last also affects 
their independence, because of the habits which occur in society. Birth order is a potentially important variable that implies physical and cognitive differences between siblings and differential access to parental resources during childhood (Courtiol et al., 2009). For example, parents tend to treat an only child is special which leaves them less independent, because their wishes are always fulfilled. For instance, when such children are always assisted to put on their clothes or shoes, they end up seeking assistance from others in society.

Parenting and birth order of children in the family determine their social behavior. Also, parental socialization is important for children, because they are young without the right experience to guide their development towards maturity. Ambron interpreted that socialization as a learning process that guides children towards the development of social personality thereby, making them become responsible and effective community members (Suryana, 2016). The association of social relationships, parents' family members, and peers, helps to develop children's social behavior.

Based on the above problems, this study aims to describe and analyze the influence of parenting on the birth order of children towards the social behavior, of kindergarten children.

\section{Methodology}

The research design used is descriptive quantitative and path analysis. While, the path analysis is used to analyze the pattern of relationships between variables to determine the direct or indirect influence of a set of exogenous on the endogenous (Riduwan, 2004).

The samples of this study were 2I4 children aged 5-6 years randomly selected using the Slovin formula from a population of 445 Kindergarten children in Gugus Anggrek, East Banjarmasin District. Data collection using a questionnaire consisted of parenting variables, with documented birth sequences, while observing the social behavior and children's independence variables. This is following the conceptual relationship model between variables as shown in the following research model:

By the conceptual model, path analysis was used to answer seven research hypotheses, namely: $\mathrm{H}_{1}$ : there is a positive and significant influence between parenting patterns and social behavior; $\mathrm{H}_{2}$ : there is a positive and significant influence between the birth order of children and social behavior; $\mathrm{H}_{3}$ : there is a positive and significant influence between parenting parents and children's independence; $\mathrm{H}_{4}$; there is a positive and significant effect between the birth order of children and the independence of children; $\mathrm{H}_{5}$ : there is a positive and significant influence between social behavior and children's independence; $\mathrm{H}_{6}$ : social behavior is an intermediary between parents' parenting style and children's independence; $\mathrm{H}_{7}$ : social behavior is an intermediary between the birth order of children and the child's independence.

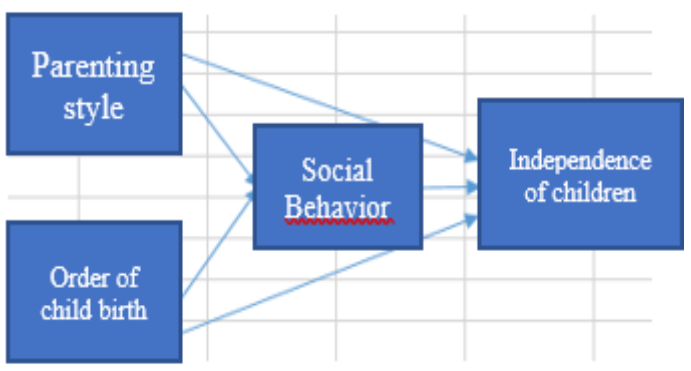

Figure I. The conceptual relationship between variable models

\section{Result and Discussion}

The results of the descriptive statistical analysis of respondents on the research variables are as follows parenting, birth order of children, social behavior, and independence. Table I is the frequency distribution of respondents based on parenting patterns.

Table I. Frequency distribution of respondents based on parenting patterns.

\begin{tabular}{lll}
\hline Category & Frequency & Percent \\
\hline Authoritarian & 36 & $16.8 \%$ \\
Democratic & $\mathrm{I} 49$ & $69.6 \%$ \\
Permissive & 29 & $13.6 \%$ \\
Total & $2 \mathrm{I} 4$ & 100 \\
\hline
\end{tabular}


Table 2. Frequency distribution of child birth sequences

\begin{tabular}{lll}
\hline Category & Frequency & Percent \\
\hline Firstborn child & 54 & $25.2 \%$ \\
Middle child & 55 & $25.7 \%$ \\
Youngest child & 85 & $39.7 \%$ \\
Only child & 20 & $9.3 \%$ \\
Total & 214 & 100 \\
\hline
\end{tabular}

\begin{tabular}{lll}
\hline Category & Frequency & Percent \\
\hline Not yet developed & 3 & $1.4 \%$ \\
Start to develop & 53 & $24.8 \%$ \\
Develop according to expectations & 97 & $45.3 \%$ \\
Very well developed & 61 & $28.5 \%$ \\
Total & 214 & 100 \\
\hline
\end{tabular}

Table 3 Frequency distribution of social behavior

Table 4. Distribution of children's independence frequencies

\begin{tabular}{lll}
\hline Category & Frequency & Percent \\
\hline Not yet developed & 4 & I.9\% \\
Start to develop & 24 & I I.2\% \\
Develop according to expectations & $\mathrm{I} 09$ & $50.9 \%$ \\
Very well developed & 77 & $36.0 \%$ \\
Total & $2 \mathrm{I} 4$ & 100 \\
\hline
\end{tabular}

In the next stage, the interpretation path analysis with multiple regression tests is carried out for each equation using structural models I and II. The summary of the results is in table 5 as follows:

Table 5. Summary of path analysis results

Structure Model I

Parenting, Order of Child Birth to Social Behavior

\begin{tabular}{lllll}
\hline Variable & Path coefficient & $\mathrm{T}$ & $\mathrm{P}$ & $\mathrm{R}^{2}$ \\
\hline Parenting & 0.203 & 3.049 & .003 & 0.069 \\
Order of Child Birth & $0.17 \mathrm{I}$ & 2.572 & $.01 \mathrm{I}$ & \\
\hline
\end{tabular}

Structure Model II

Parenting order of Child Birth and Social Behavior towards Children's Independence.

\begin{tabular}{lllll}
\hline Variable & $\begin{array}{l}\text { Path } \\
\text { coefficient }\end{array}$ & $\mathrm{T}$ & $\mathrm{P}$ & $\mathrm{R}^{2}$ \\
\hline Parenting & 0.144 & 2.438 & 0.016 & \\
Order of Child Birth & 0.146 & 2.498 & 0.013 & $0.30 \mathrm{I}$ \\
Social Behavior & 0.459 & 7.666 & 0.000 & \\
\hline
\end{tabular}


Table 6. Summary of Hypothesis Testing Decisions $\mathrm{H}_{1}, \mathrm{H}_{2}, \mathrm{H}_{3}, \mathrm{H}_{4}$, and $\mathrm{H}_{5}$

\begin{tabular}{|c|c|c|}
\hline Hypothesis & $\mathrm{p}$ & Decisions \\
\hline $\begin{array}{l}\mathrm{H}_{1} \text { There is a positive and significant influence between parenting and } \\
\text { social behavior }\end{array}$ & 0.003 & Accepted \\
\hline $\begin{array}{l}\mathrm{H}_{2} \text { There is a positive and significant influence between the birth order of } \\
\text { children and social behavior }\end{array}$ & $0.01 \mathrm{I}$ & Accepted \\
\hline $\begin{array}{l}\mathrm{H}_{3} \text { There is a positive and significant influence between parenting and } \\
\text { children's independence }\end{array}$ & 0.016 & Accepted \\
\hline $\begin{array}{l}\mathrm{H}_{4} \text { There is a positive and significant influence between the order of } \\
\text { childbirth and independence }\end{array}$ & 0.013 & Accepted \\
\hline $\begin{array}{l}\mathrm{H}_{5} \text { There is a positive and significant influence between social behavior } \\
\text { and independence }\end{array}$ & 0.000 & Accepted \\
\hline
\end{tabular}

Table 7. Summary of Hypothesis Testing Decision $\mathrm{H}_{6}$ and $\mathrm{H}_{7}$

\begin{tabular}{|c|c|c|c|}
\hline \multirow{2}{*}{ Hypothesis } & \multicolumn{2}{|c|}{ Coefficient of Effect } & \multirow{2}{*}{ Decisions } \\
\hline & Direct & Indirect & \\
\hline $\begin{array}{l}\text { H6 Social behavior is an intermediary which } \\
\text { influences parenting and independence }\end{array}$ & $0 . \mathrm{I} 44$ & 0.093 & $\begin{array}{l}\text { Not } \\
\text { accepted }\end{array}$ \\
\hline $\begin{array}{l}\mathrm{H}_{7} \text { Social behavior is an intermediary which } \\
\text { influences the birth order of children and their } \\
\text { independence }\end{array}$ & 0.146 & 0.078 & $\begin{array}{l}\text { Not } \\
\text { accepted }\end{array}$ \\
\hline
\end{tabular}

Descriptive analysis of frequencies in tables I-4 answers the first hypothesis on the description of parenting, childbirth order, social behavior, and independence using the research hypothesis formulated with the decisions in Tables 6 and 7. Table 6 summarizes the decisions of $\mathrm{H}_{1}, \mathrm{H}_{2}, \mathrm{H}_{3}, \mathrm{H}_{4}$, and $\mathrm{H}_{5}$ with an accepted criterion significance value of less than 0.05 . Table 7 summarizes the decision of testing the hypothesis $\mathrm{H}_{6}$ and $\mathrm{H}_{7}$ with the provisions that when the coefficient of indirect effect is greater than 0.05, then the hypothesis is not accepted. Based on the description of parenting analysis in tables I to 4, democracy consists of I49 people and $69.6 \%$. While the birth order of most children is in the position of the youngest child with a total of 85 people and $39.7 \%$. The social behavior in the category of developing according to expectations had several 97 people with a percentage of $45.3 \%$, while the independence of children for the development category consists of I09 people and $50.9 \%$.

There is an Influence of Parenting and Social Behavior

The structural model in table 5, found that both have a direct influence on parental care and social behavior with the calculated result 0.003 $<0.05$. Also, the magnitude of the correlation coefficient pathway regarding parents and social behavior was 0.203 .

According to the finding, the application of parenting determines a child's behavior in the social environment. Wood and Zoo stated that parenting is a pattern of interaction relationships between parents and children, following their attitudes, or behaviors including how to apply rules, teach values, provide attention, and affection for their children (Madyawati, 2016).

The role of the family is very important in the formation of children's character because parents are a strong foundation for character development in early childhood, primary, secondary, and higher educations (Andriyani et al., 2018). It is important to understand child socialization values not only as individual parents' preference in child rearing but also as societal norms and expectations that define national culture (Su - Yun and Min Jung, 2015).

This shows that parenting plays an important role in the attitudes and behaviors displayed by children. The findings of this study also support that each parent is the main education for their children, with the ability to care, provide education, and guide them from 
birth. It means that education in the family is and cannot be replaced by any institution. A harmonious and peaceful family is reflected in the psychological condition and character of their children and vice versa. (Wibowo, 2017).

Parenting plays an important role in fostering the social behavior of children, with the ability to shape, protect and guide them towards maturity (Putri et al., 2019).

Increasingly complex and reciprocal interactions that occur between children and parents when children develop directly shape the experiences of their children based on their interactions (Park and Lau, 20I5).

\section{There is an Influence of Child Birth Order and Social Behavior}

The structural model in table 5 , found a direct influence on the birth order of children and social behavior with a result of 0.0 I I $<0.05$, with a correlation coefficient path of 0.I7I. These findings stated that the birth order of children contributes to their social behavior. According to Freud, the influence of family environment on children's development is a starting point for the development of their social abilities. This in line with the opinion of other experts, which stated that the relationship between humans in the family influences the social development of a child, such as a relationship between parents and siblings. Also, the position of children in the family and the number of members affect their social development (Soemantri, 2012).

According to Desmita (20I5), parents have attitudes, treatments and provide specific roles to single children, the eldest, middle, or youngest, which influences their personality and formation toward themselves and others.

Alfred Adler alludes to the influence of the birth order of children on the formation of the nature of a person which determines their fate later in life. According to Adler, "an only child has difficulty in carrying out free activities related to others and tends to be worthless to the society" (Hadibroto et al., 2002).

\section{There is an Influence of Parenting and Children's Independence}

Based on the results of the research findings in table 5, there is an influence of parenting on children's independence with a significance of $0.016<0.05$. Also, the magnitude of the correlation coefficient between parents on children's independence is 0.I44. Wibowo (2017), stated that parenting style is one of the factors which significantly or fundamentally helps to shape the character of children.

Parental involvement in the development of early childhood character is through building positive communication (Maimunah, Aslamiah, \& Ahmad Suriansyah, 2018) which is defined as an activity that is always carried out by everyone irrespective of their location (Suriansyah A., 20I4).

Meanwhile, Hurlock, 2004, explained that parents with the best cultural values in treating their children democratically pay attention to their activity and needs in the family and school environment. Similarly, Helmawati (20I4) stated that children tend to be independent when parents educate and train them properly with good faith, and morals.

Furthermore, supports from parents, qualified teachers, and the environment helps in processing character education (Cinantya et al., 2018).

Lestari (20I4), stated that democratic, permissive and authoritarian parenting influences early childhood independence. Children with high, low and no independence tend to experience democratic, authoritarian and permissive parenting.

There is an Influence of Child Birth Order and Child Independence

The structural model II in table 5, influence childbirth order and independence with a significance value of $0.016<0.05$ and 0.144 correlation coefficient. The findings of this study are following Soetjiningsih (20I4) which stated that the birth order can affect environment treatment, relationships with other members, and the specific role of children. This affects the attitudes, behavioral patterns, and types of personal/social adjustments performed by individuals. Every child in the family has a position with different responsibilities and consequences. This is due to the culture and attitudes of different parents, that recognize the existence of first, middle, youngest, an only child.

According to Hurlock (2004), the eldest child has the characteristics of mature behavior because it deals with adults and is expected to 
assume responsibility, less aggressive and courageous due to excessive parental protection. The middle children tend to possess independent learning and adventure due to greater freedom, while the youngest child has greater security.

Also, it is in line with the fact that an only child is usually close to their parent, resulting in maturity behavior which has a good effect on their relationships with peers. Excessive protection from parents, lack of envy and competition between siblings, given by parents to children leads to high academic, sports, and social achievements, (Hurlock, 20I5). Muchsinati (2007) stated that firstborns are more independent than the middle, while the youngest child is more independent than the middle.

There is an Influence between Social Behavior and Children's Independence

Based on the results of the research findings in table 5, the structural model II influences the social need and independence of children with a significance value of $0,000<0.05$ and a correlation coefficient of 0.459 .

The findings of this study confirm with Somantri (2012) research on social behavior which is reflected in an attitude shown voluntarily by children, through help, and donations. Also, groups of friends in the same age, help children gain independence, with the ability to think, and air their opinions.

According to Hurlock (2014) children help themselves to achieve independence from parents through relationships with peers. This is divided into two aspects, namely internal and external relationships. The internal consists of activities carried out in the family which need to be conducted independently at home.

Zimmerman stated that an independent child has high self-confidence and intrinsic motivation. These are the main keys to independence, and with such confidence, children dare to appear and express themselves in public, without looking shy, rigid, or awkward (Susanto, 2017).

There is an indirect effect between Parenting and Children's Independence through Social Behavior.

The calculation results of table 7 , produces a direct effect of 0.093 , which is greater than the indirect, therefore $\mathrm{HO}$ is not accepted.
The results of this study indirectly indicate that parenting through social behavior has no significant effect on children's independence, because the result of the direct effect is greater than the indirect.

There are indirect effects between childbirth order and independence through social behavior

The calculation result on table 7 , has a direct influence of 0.078, which means it is greater than the indirect effect and not accepted.

The results of this study indirectly indicate that there is no significant effect on the order of birth of children through social behavior.

\section{Conclusion and Recommendation}

It is concluded that there is a significant influence between parenting patterns of social behavior, with a significant influence between the birth order, social behavior, and independence of children. Furthermore, there is an indirect effect between parenting patterns on the social behavior of children's independence and childbirth. Education stakeholders are recommended to strengthen cooperation between parents and the Department of Education in making parenting programs and improving communication to foster better child development.

\section{Acknowledgment}

The authors are grateful to all those that supported this research, especially the principals, teachers, and parents of the Gugus Anggrek Kindergarten, East Banjarmasin Subdistrict, as well as the Office of Education and Culture of the City of Banjarmasin for providing opportunities and recommending this research.

\section{References}

Afifah, N., Suriansyah, A., \& Aslamiah. (2019). Implementasi Kurikulum Berbasis Aqidah Islam. Banjarmasin: Pascasarjana Universitas Lambung Mangkurat.

Andriyani, E., Ngadimun., \& Suriansyah, A. (2018). Character education management. IOSR Journal of Research \& Method in Education (IOSR-JRME), 8(6), I2-I8. 
Cinantya, C., Suriansyah, A., \& Asniwati, A. (2018). The model of religion-based character education (multi-site integrated islamic PAUD Sabilal Muhtadin and PAUD Islam Mawaddah Banjarmasin, Indonesia). European Journal of Education Studies, $5(7), \quad$ I-I3. doi: I0.528I/zenodo.I494I58.

Courtiol, A., Raymond, M., \& Faurie C. (2009). Birth Order Affects behavior in the Investment Game: Firstborns Are Less Trustful. Animal Behaviour, 78(6):I405I4I I. doi: 10.1016/j.anbehav.2009.09.016

Desmita. (20I5). Psikologi Perkembangan. Bandung: PT. Remaja Rosdakarya.

Djamarah, S. B. (2014). Pola Asuh Orang Tua dan Komunikasi dalam Keluarga: Upaya Membangun Citra Membentuk Pribadi Anak. Jakarta: PT. Rineka Cipta.

Fadillah, M., \& Khorida, L. M. (2016). Pendidikan Karakter Anak Usia Dini: Konsep dan Aplikasinya dalam PAUD. Jogjakarta: Ar-Ruzz Media.

Hadibroto, I., Alam, S., Suryaputra, E., Olivia, F. (2002). Misteri Perilaku Anak Sulung, Tengah, Bungsu, dan Tunggal. Jakarta: Gramedia Pustaka Utama.

Hamdanah. (2017). Bunga Rampai Ilmu Pendidikan Islam. Banjarmasin: Pustaka Buana.

Helmawati, (2014). Pendidikan Keluarga: Teoretis dan Praktis. Bandung: PT. Remaja Rosdakarya.

Hurlock, E. B. (2004). Psikologi Perkembangan Suatu Pendekatan Rentang Kehidupan. Jakarta: Erlangga.

Hurlock, E. B. (2014). Perkembangan Anak (Jilid I). Jakarta: Erlangga.

Hurlock, E. B. (20I5). Perkembangan Anak (Jilid 2). Jakarta: Erlangga.

Latifah, MS, W., \& Metroyadi. (2019). Pengaruh Pendidikan, Pekerjaan dengan Pengasuhan Terhadap Kemandirian Anak. Banjarmasin: Pascasarjana Universitas Lambung Mangkurat

Lestari, S. D. (2014). Pengaruh Pola Asuh Orang Tua terhadap Kemandirian Anak Usia Dini (Usia 3-5 Tahun): Studi pada keluarga di kelurahan Gunung Puyuh Kecamatan Gunung Puyuh Kota Sukabumi. Other Thesis. Universitas Pendidikan Indonesia. http://repository.upi.edu/67I I/
Madyawati, L. (2016). Strategi Pengembangan Bahasa pada Anak. Jakarta: Kencana Prenadamedia Group.

Maimunah, M., Aslamiah, A., \& Suriansyah, A. (2018). The integration of sentra-baed learning and involement of family program at early childhood in developing character building (multi case at PAUD Mawaddah and PAUD Alam Berbasis Karakter Sayang Ibu Banjarmasin, Indonesia. European Journal of Education Studies, 5(7), 49-63. doi:I0.528I/zenodo. I494207.

Muchsinati, N. (2007). Hubungan urutan kelahiran dalam keluarga dengan kemandirian anak usia dini di TK Madinah Malang. Tesis. Universitas Islam Negeri Malang. http://etheses.uinmalang.ac.id.

Nur, A. H., \& Karismatika, I. (2019). Pengaruh Pola Asuh Orang Tua terhadap Minat Belajar Siswa Kelas VIII di SMP Negeri 7 Jember Tahun Pelajaran 2017-2018. Jurnal Bimbingan Konseling dan Pendidikan, I (I), I-9.

Park, H., \& Lau, A. S. (2015). Socioeconomic Status and Parenting Priorities: Child Independence and Obedience Around the World. Journal of Marriage and Family, $78(\mathrm{I}), \mathrm{I}-\mathrm{I} 7$.

Putri, H., Suriansyah, A., \& Wahdini. (2019). Pengaruh Tingkat Pendapatan dan Tingkat Pendidikan dengan Pola Asuh Orang Tua terhadap Perilaku Sosial Anakdi TK Kecamatan Sambas Kalimantan Barat. Cakrawala Pendidikan. 3.

Rakhma, E. (2017). Menumbuhan Kemandirian Anak. Jogjakarta: CV. Diandra Primamitra Media.

Riduwan. (2004). Metode dan Teknik Menyusun Tesis. Bandung: Alfabeta.

Safitri, M. E., Ahmad, K. I., \& Saleh, M. (2018). Development of child independence through model picture and picture, examples non examples model and practical method directly activities of learning practical life in Group B Kasih Ibu Kindergarten. Banjarmasin. European Journal of Education Studies, 5(7), 77.

Soetjiningsih, C. H. (20I4). Seri Psikologi Perkembangan: Perkembangan Anak Sejak Pembuahan sampai dengan Kanak-kanak Akhir. Jakarta: Prenadamedia Group. 
Somantri, S. (2012). Psikologi Anak Luar Biasa. Bandung: PT. Refika Aditama.

Su -Yun, P., \& Min Jung, K. (2005). Korean Mothers Ideal \& Actual Parenting Behaviors Toward Their Young Childreen as a Function of Child Gender, Age, and Birth Order. International Journal of Human Ecology, 7(2), 85-95.

Suriansyah, A. \& Aslamiah. (2015). The leadership strategies of school principals, teachers, parents, and the communities in building the students' character. Cakrawala Pendidikan: Jurnal Pendidikan Ilmiah, 27(2), I-I4.

Suriansyah, A. (20I4). The relationship between school culture, communication, and commitment and the state elementary school teachers' performance. Cakrawala Pendidikan: Jurnal Ilmiah Pendidikan, 33 (3), I-IO.

Suryana, D. (2016). Pendidikan Anak Usia Dini: Stimulasi dan Aspek Perkembangan Anak. Jakarta: Kencana Prenadamedia Group.
Susanto, A. (2017). Pendidikan Anak Usia Dini (Konsep dan Teori). Jakarta: PT. Bumi Aksara.

Wahdini, C. S., \& Suriansyah, A. (2019). The effect of parents of the parents and the position of children with family strengths on self-assistance of $\mathrm{tk}$ children in the group of Bangkari Kelompok B Palangkaraya. Cakrawala Pendidikan: Jurnal Ilmiah Pendidikan, 8(4): I-9.

Wibowo, A. (2017). Pendidikan Karakter Usia Dini: Strategi Membangun Karakter di Usia Emas. Yogyakarta: Pustaka Pelajar.

Wiyani, N, A. (2015). Bina Karakter Anak Usia Dini: Panduan Orangtua dan Guru dalam Membentuk kemandirian dan Kedisiplinan Anak Usia Dini. Jogjakarta: Ar-Ruzz Media.

Zain, A., Saleh, M., \& Noorhapizah. (2018). Strategy for the development of religious worship and religious tolerance at Widya Dharma PAUD in Banjarmasin City. Indonesia: European Journal of Education Studies, 5(7), 89. 